\title{
Igneous Activity and Structural Development of the Mianhua Terrace, Offshore North Taiwan
}

\author{
Jih-Hsin Chang ${ }^{1, *}$, Eason Yi-Cheng Yang ${ }^{2}$, Ho-Han Hsu ${ }^{1,2}$, Tzu-Ting Chen ${ }^{1,2}$, Char-Shine Liu ${ }^{2}$ \\ and Shye-Donq Chiu ${ }^{1}$ \\ 1 Institute of Oceanography, National Taiwan University, Taipei 10617, Taiwan; hhhsu@ntu.edu.tw (H.-H.H.); \\ pingpingting326@gmail.com (T.-T.C.); sdchiu@ntu.edu.tw (S.-D.C.) \\ 2 Ocean Center, National Taiwan University, Taipei 10617, Taiwan; zirconpyrite@gmail.com (E.Y.-C.Y.); \\ csliu@ntu.edu.tw (C.-S.L.) \\ * Correspondence: changjihhsin@ntu.edu.tw
}

Citation: Chang, J.-H.; Yang, E.Y.-C.; Hsu, H.-H.; Chen, T.-T.; Liu, C.-S.; Chiu, S.-D. Igneous Activity and Structural Development of the Mianhua Terrace, Offshore North Taiwan. Minerals 2021, 11, 303. https://doi.org/10.3390/min11030303

Academic Editor: Craig Magee, Qiliang Sun and William McCarthy

Received: 1 January 2021

Accepted: 9 March 2021

Published: 16 March 2021

Publisher's Note: MDPI stays neutral with regard to jurisdictional claims in published maps and institutional affiliations.

Copyright: (c) 2021 by the authors. Licensee MDPI, Basel, Switzerland. This article is an open access article distributed under the terms and conditions of the Creative Commons Attribution (CC BY) license (https:// creativecommons.org/licenses/by/ $4.0 /)$.

\begin{abstract}
Using bathymetric and multichannel seismic (MCS) data, we explored the volcanic influence on the bathymetric and stratigraphic features of the Mianhua Terrace. The Mianhua Terrace occupies the marine counterpart of the Northern Taiwan Volcanic Zone (NTVZ) along the collapsed Taiwan orogenic wedge and is dominated by post-collisional magmatism and extensional structures. The bathymetric data showed several semicircular-shaped features near the shelf break. The MCS profiles showed that the Pleistocene unconformity buried beneath the Mianhua Terrace is partly difficult to observe due to seafloor multiples, suggesting that the seafloor is dominated by physically hard lithology, probably volcanic lavas. We interpreted the high-amplitude reflectors and their projected seafloor relief as intrusive sills and associated extrusive edifice. Similarly, we interpreted high-amplitude reflectors in the vicinity of normal faults as intrusive sills emplaced and facilitated by fault structures. A volcanic or hydrothermal mound was also recognized. We propose that the Mianhua Terrace is a breached ramp in a transfer zone between the tips of two successive normal faults along the shelf break. Once the fault tips reactivate and extend toward each other, the Mianhua Terrace may continue to collapse, leading to catastrophic volcanic or associated hydrothermal events.
\end{abstract}

Keywords: Mianhua Islet; fault; sill; lava; volcanic edifice; MCS; Northern Taiwan

\section{Introduction}

Igneous and volcanic activities are commonly seen in post-collisional tectonic environments and are known as post-collisional magmatism [1-4]. Post-collisional structures postdate the cessation of the collision, probably due to the transfer of tectonic stress, and are generally characterized by extensional structures [5-8]. Concerning rock geochemistry, post-collisional magmatism generally occurs with specific geochemical patterns and spatiotemporal distribution. Nevertheless, the geological structures of post-collisional magmatism are rarely geophysically imaged, and their structural features within the post-collisional framework are barely mentioned.

The growth of the Taiwan orogenic wedge was diachronous from north to south, and Northern Taiwan is currently at its post-collision stage (Figure 1) [9-13]. Regional magmatism features the Northern Taiwan Volcanic Zone (NTVZ) dominated by post-collision magmatism, including inland Tatun, Kuanyin, and Keelung volcanic groups, and offshore volcanic Mianhua, Huaping, and Pengchia Islets (Figure 2) [14,15]. A recent seismological study showed an active magma chamber of $350 \mathrm{~km}^{3}$ in volume and $15 \mathrm{~km}$ in depth existing beneath the northeastern coast of Taiwan [16]. In fact, magmatism and associated hydrothermal alternation in the volcanic-sedimentary sequence resulted in Pleistocene epithermal mineralization and a gold-copper deposit in Chinkuashih, Northern Taiwan, and over 94 tons of gold were mined from 1898 to 1987 [17,18]. Post-collisional magmatism 
in Northern Taiwan is thus of great importance, not only for potential geological hazards but also for prospective economic mining resources.

Mianhua Terrace is a distinct, bathymetric terrace connecting the shelf break and the Mianhua Canyon north of offshore Taiwan (Figures 1 and 3). Located immediately south of the post-collisional volcanic Mianhua and Huaping Islets and occupying the marine counterpart of the NTVZ and collapsed Taiwan orogenic wedge, the Mianhua Terrace is conceivably dominated by post-collisional magmatism and associated events. In fact, a documented historical record of eruption events has been reported for this area, revealing that submarine eruption events may have occurred on a time scale of hundreds of years [19]. Apparently, post-collisional magmatism and associated events have profound influence on stratigraphic architectures and structures in the Mianhua Terrace. Thus, offshore Northern Taiwan is a superior candidate to study how post-collisional magma ascends through the crust and how magmatic intrusions are emplaced at stratigraphic levels.

The objective of this study was to explore the geological features associated with postcollisional magmatism and the emplacement of magmatic intrusions and extrusions, as well as to investigate the origin of the Mianhua Terrace within the framework of post-collisional collapse and magmatism. Taking advantage of recently compiled marine bathymetric and multichannel seismic (MCS) data, we preliminarily describe volcanic-associated bathymetric, stratigraphic, and structural features, and we discuss their possible geometry, origin, and age. We propose that the Mianhua Terrace occupies a breached ramp of a transfer zone located between the tips of two post-collisional, extensional, normal faults, and that it will become catastrophic if the normal faults and associated volcanisms are reactivated. This model indicates that the potential geohazard risk caused by the Mianhua Terrace and the prospective submarine mining resource in the Mianhua Terrace should not be underestimated. We suggest that the Mianhua Terrace is not only an active volcanic field but also likely a prospective site with hydrothermal events and associated mineralization.

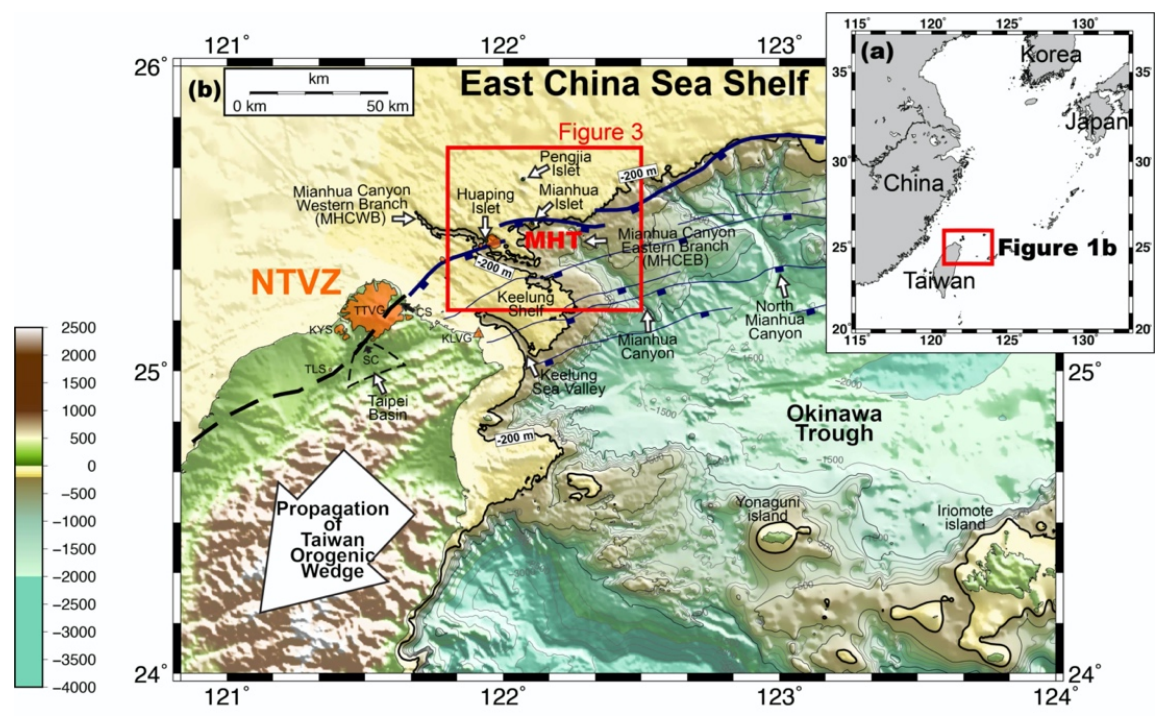

Figure 1. Maps of East Asia (a) and northeast offshore Taiwan (b). The large empty arrow indicates the propagation of the Taiwan orogenic wedge. The blue lines indicate extensional normal faults caused by mountain collapse, and the thick blue line indicates the westernmost one [12]. The black dash line indicates the position of the deformation front $[11,20]$. Orange areas indicate the Northern Taiwan Volcanic Zone (NTVZ) [14]. Green dots indicate the distribution of the Quaternary islets. Note that the strikes of the normal faults are parallel to the strike of the orogenic wedge, and the NTVZ is situated almost along the tectonic strike. MHT: Mianhua Terrace; TTVG: Tatun Volcanic Group; TLS: Tsaolingshan; SC: Shanchiao Fault; CS: Chinshan Fault. 


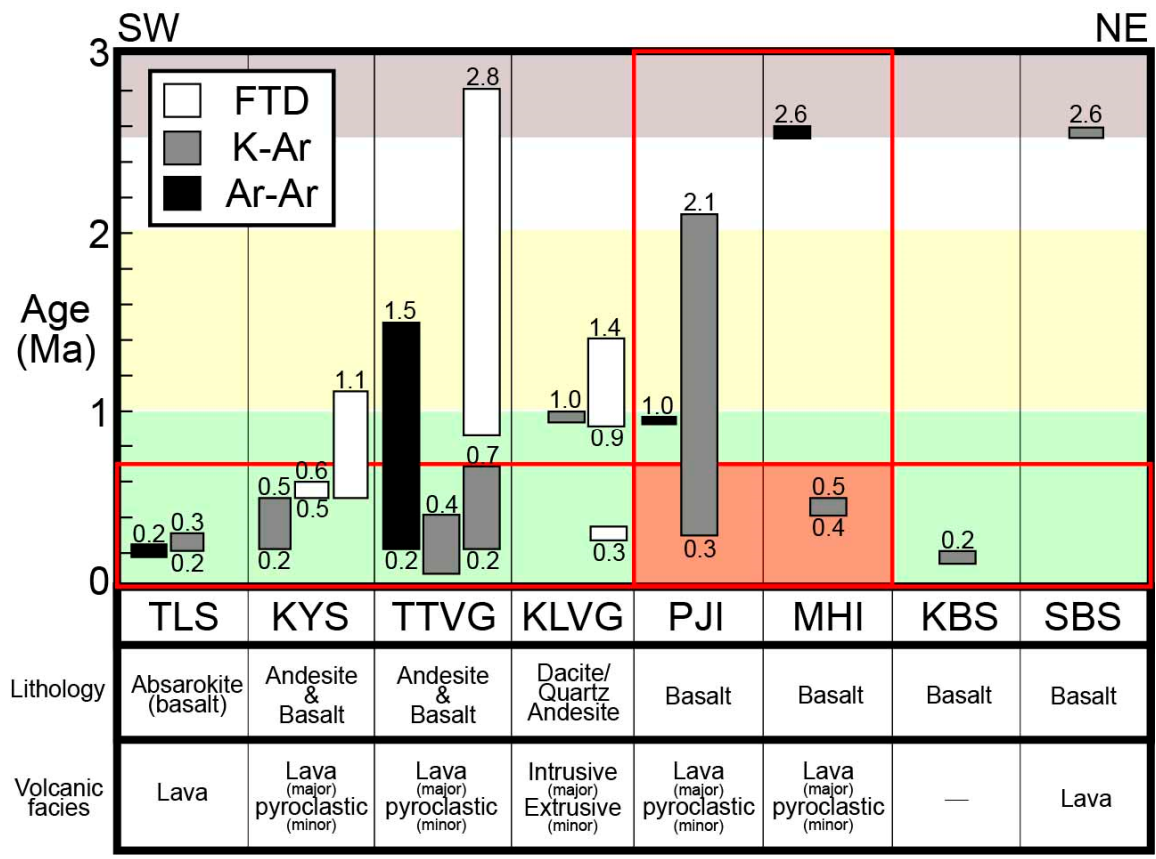

Figure 2. Radiometric age data for the volcanic fields in the NTVZ [15]. FTD: fission track dating; TLS: Tsaolingshan; KYS: Kuanyinshan; TTVG: Tatun Volcanic Group; KLVG: Keelung Volcanic Group; PJI: Pengjia Islet; MHI: Mianhua Islet; SBS: Sekibisho; KBS: Kobisho. See text for the references.

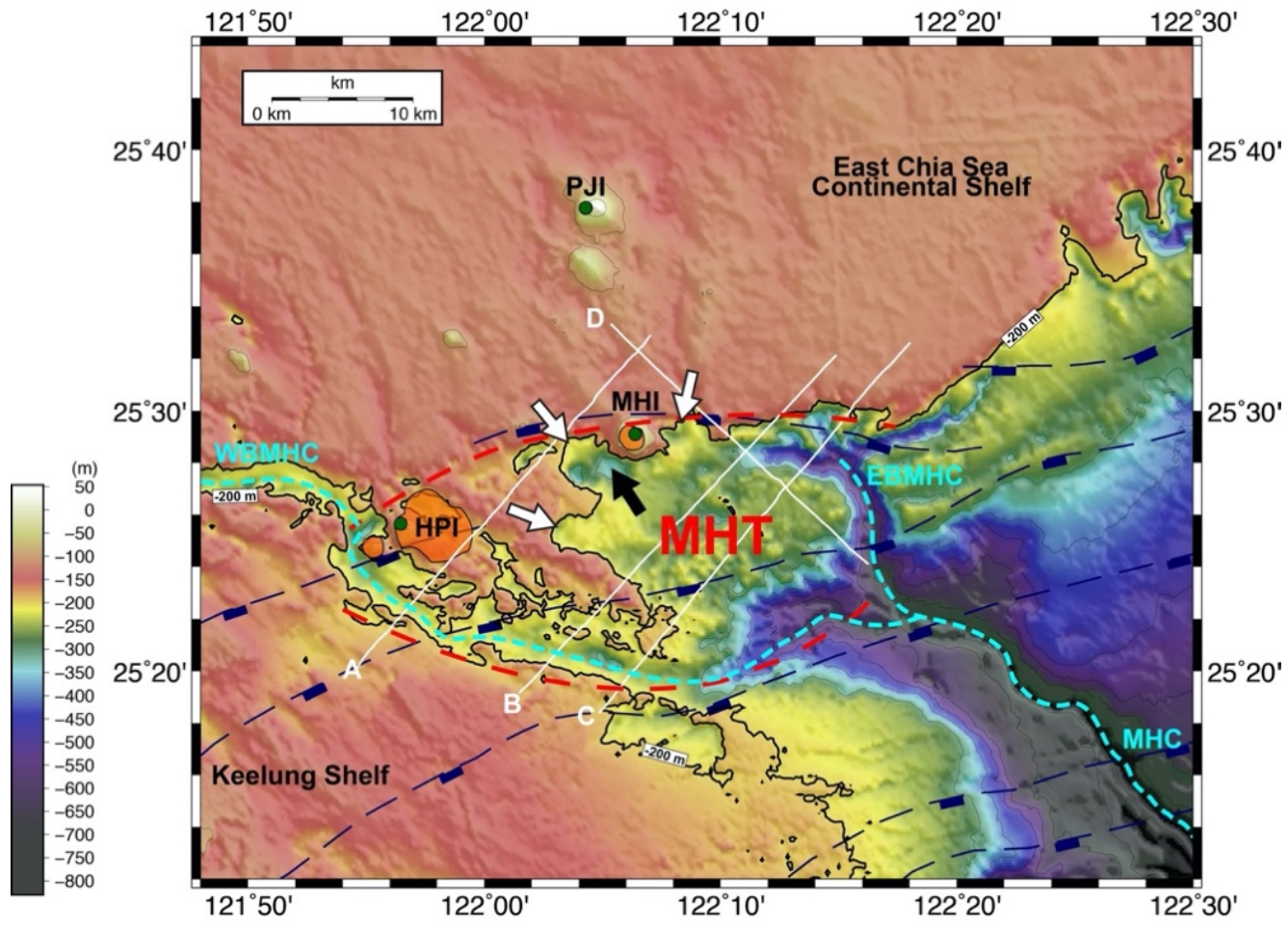

Figure 3. A $200 \mathrm{~m}$ grid bathymetric map showing the Mianhua Terrace (MHT) and distribution of the multichannel seismic (MCS) data. Light blue dashed lines indicate the thalweg of the Mianhua Canyon. Blue lines indicate extensional normal faults [12]. Orange areas indicate the Northern Taiwan Volcanic Zone (NTVZ) [14]. Green dots indicate the distribution of the Quaternary volcanic islets (HPI: Huaping Islet; MHI: Mianhua Islet; PJI: Pengjia Islet). White lines A, B, C, and D indicate the distribution of the MCS data. MHC: Mianhua Canyon; MHCWB: Mianhua Canyon West Branch; MHCEB: Mianhua Canyon East Branch. 


\section{Geological Setting}

\subsection{Regional Structure}

Since the Late Miocene, the Taiwan orogenic wedge was formed by oblique collision between the Luzon arc and Eurasian continent, growing diachronously from north to south (Figure 1) [9-11]. Southern Taiwan and central Taiwan are considered at the stages of the inception and climax of mountain building processes, respectively, and they are suggested to be among the best places to study the development of the fold-thrust belt [21]. Northern Taiwan is now experiencing the stage of the mountain collapse and is in the extensional strain field [22]. For example, Taipei Basin in Northern Taiwan (Figure 1) is a Quaternary extensional basin floored with a basement of collapsed Tertiary rock. Further north, the collisional mountains have collapsed even earlier and have sunk below sea level.

The post-collision mountain collapse in offshore Northern Taiwan is marked by a Pleistocene unconformity and is dominated by reactivated normal fault structures [12]. The fault structures in offshore Northern Taiwan were formed initially during pre-Pleistocene collision events, which resulted in a fold-thrust belt and a series of reverse faults, such as those that can be observed in current central Taiwan. After the collision stage, the regional stresses changed from compressional to extensional. The reverse fault became an inherited structure that the normal faults are able to develop along, showing a change in the slip sense from a compressional reverse sense to an extensional normal sense.

As the regional stress changed from compressional to extensional, the frontal tip of the fold-thrust belt, which separates the undeformed area from the deformed area, became a structural boundary, especially in terms of the development of fault structures. Accordingly, the deformation front of the Taiwan orogenic wedge roughly separates the foreland basin to the west from the mountain belt to the east in the terrestrial domain (thick black dash line in Figure 1) [11,20], and it separates the less deformed East China Sea continental shelf to the west from the deformed, collapsed Taiwan orogenic wedge to the east in offshore Northern Taiwan (thick blue dash line in Figure 1) [12]. West of the Taipei Basin, the deformation front seems to run approximately along the Shanchiao Fault [23], an active normal fault with documented paleoearthquakes in the Taipei metropolis [24]. Along the northward extension of the Shanchiao Fault, the deformation front runs seemingly along the Chinshan Fault, which has an at-least $7 \mathrm{~km}$ extension observed in the underwater domain [25]. Farther north, the deformation front seems extended roughly along the shelf break, separating the continental shelf from the slope (Figures 1 and 3).

\subsection{Northern Taiwan Volcanic Zone (NTVZ)}

In addition to the collapsed collisional mountain belt, Northern Taiwan is also characterized by the NTVZ (Figure 1) [14,15]. Three age groups are recognized (Figure 2). The first age group (before 2.6 Ma) includes the Tatun volcanic group (2.8 Ma), Mianhua Islet (2.6 Ma), and Sekibisho (2.6 Ma), and it may represent the earliest signals of postcollision. The second age group (2 1 Ma) includes the Pengjia Islet (2.1 Ma), the Tatun volcanic group (1.5 Ma), and the Keelung volcanic group (1.4 Ma), approximately coeval to the formation of the regional unconformity that represents the onset of fault-controlled subsidence [13]. The third age group (after $1 \mathrm{Ma}$ ) is the youngest group and is extensively distributed, mostly all over the NTVZ.

The NTVZ includes not only volcanoes in the terrestrial domain but also offshore volcanic islets more than $30 \mathrm{~km}$ away from Taiwan. Among them, the Huaping and Mianhua Islets are located approximately along the shelf break and are about 32 and $42 \mathrm{~km}$ away from Taiwan, respectively. Toward the northwest, Pengjia Islet located west of the shelf break is $56 \mathrm{~km}$ away from Taiwan. Though there are only three volcanic islets, we should note that volcanism also occurs underwater and may not be visible above sea level. In fact, recent observations have shown some subsurface volcanic features [12] and seafloor edifices [23]. Therefore, the number of volcanoes and the volcanic activity offshore from Northern Taiwan are very likely to have been underestimated. 
The lithologies and facies of the NTVZ volcanic rocks appear variable. The northernmost islets, Sekibisho (lavas) and Kobisho, consist of basalt [15]. Toward the southwest, Pengjia and Mianhua Islets are also composed of basalt and are characterized by lavas $[15,26]$. Southward to the on-land part, however, the lithologies of the Keelung volcanic group are dominated by intrusive dacite [14], quartz andesites [27-29], and extrusive andesite (lavas and tuffs) [14]. West of the Keelung volcanic group, the Tatun volcanic group and Kuanyinshan are dominated by andesite and basalt $[15,20]$. The volcanic facies of the Tatun volcanic group and Kuanyinshan are dominated by interbedded lavas and pyroclastic flow deposits $[20,30,31]$. At the far southwest end of the NTVZ, the volcanic rocks in the Tsaolinshan feature absarokite and occur as lava flow deposits [15,32]. It has been concluded that from the NE to the SW in the NTVZ, the magmas show systematic compositional variations, from low-K to calc-alkaline, and then shoshonitic, mainly occurring as lava flow deposits [15]. In addition, two mantle sources (depleted asthenosphere mantle and metasomatized lithospheric mantle) have been proposed to account for young eruption events at Mianhua Islet.

\subsection{Mianhua Terrace}

Several submarine morphological features can be observed along the shelf break in offshore Northern Taiwan, connecting the East China Sea continual shelf and the Okinawa Trough: Keelung Sea Valley, Mianhua Canyon, and Northern Mianhua Canyon (Figure 1). These canyons have received the attention of many previous studies, and the geological features of these canyons have been preliminarily investigated [33-40].

Mianhua Terrace is bounded by a shelf break (i.e., $200 \mathrm{~m}$ isobath) to the north, the Mianhua Canyon West Branch (MHCWB) to the west and south, and the Mianhua Canyon East Branch (MHCEB) to the east. It divides the Mianhua Canyon into western and eastern branches at its upper reach (Figure 3). In fact, the Mianhua Terrace is bounded not only by the bathymetric shelf break but also structurally by the reactivated normal faults to both the north and south. Furthermore, the existence of the volcanic Huaping and Mianhua Islets implies that associated volcanism may also have an influence on the nearby Mianhua Terrace. The nature of the Mianhua Terrace, however, has received only very little attention.

\section{Materials and Methods}

A recently compiled $200 \mathrm{~m}$ bathymetry grid around Taiwan $\left(119^{\circ} \mathrm{E}-123^{\circ} \mathrm{E}\right.$ longitude and $21^{\circ} \mathrm{N}-26^{\circ} \mathrm{E}$ latitude) released in 2013 was made by the Ocean Data Bank, Ministry of Science and Technology (ODB, MOST) (Figure 3). This dataset mainly consists of the shipboard data of Taiwanese Research Vessel Ocean Researchers 1, 2, and 3. With better resolution than the previous version $(500 \mathrm{~m})$, this dataset can provide more detail about local morphology. More details about this bathymetric dataset can been found via http: / / www.odb.ntu.edu.tw / bathy / (accessed on 25 November 2016). The MCS data were collected by R/V Ocean Researchers 2. Profiles A and C were collected in 2007 and were derived by ODB (see details via http: / / www.odb.ntu.edu.tw/ seisdb (accessed on 25 November 2016). Profiles B and D were collected by Seismic Exploration Laboratory, Institute of Oceanography, National Taiwan University, in 2015. Profiles A (Figures 4 and 8a), B (Figures 5 and 8b), and C (Figures 6, 8c and 9a,c) trend in the NE-SW direction along the strike of the orogenic wedge, running mainly across only the western part of the Mianhua Terrace and showing the influence of the collapsed orogenic wedge. Perpendicular to these profiles, Profile D (Figures 7 and 9a) runs across the Mianhua Terrace in the NW-SE direction, showing stratigraphic, structural, and volcanic features in different orientations. 
To estimate the geophysical response of the observed geological features, maps of potential field data, including global gravity anomaly and magnetic data, were prepared. The gravity anomaly global 1-minute dataset was accessed from Scripps Institution of Oceanography, University of California, San Diego (https: / / topex.ucsd.edu (accessed on 17 May 2017)) [41,42]. The magnetic anomaly EMAG2 dataset was accessed from National Oceanic and Atmospheric Administration (https:/ / www.ngdc.noaa.gov/geomag/emag2 .html (accessed on 17 May 2017)).
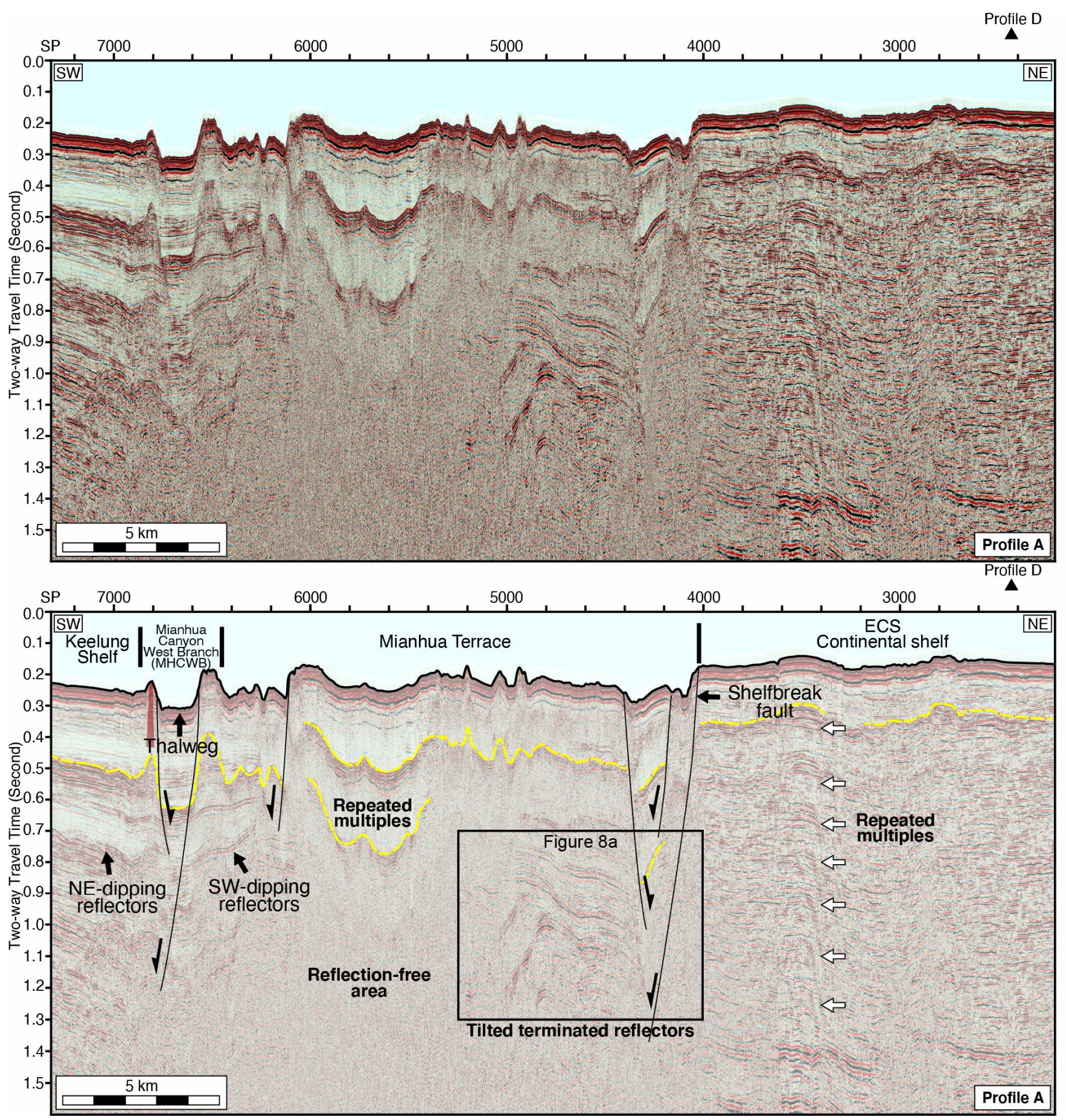

Figure 4. Multichannel seismic (MCS) data of Profile A across the Mianhua Terrace in the NE-SW direction. Brown area indicates the volcanic extrusion. Yellow lines indicate seafloor multiples. 


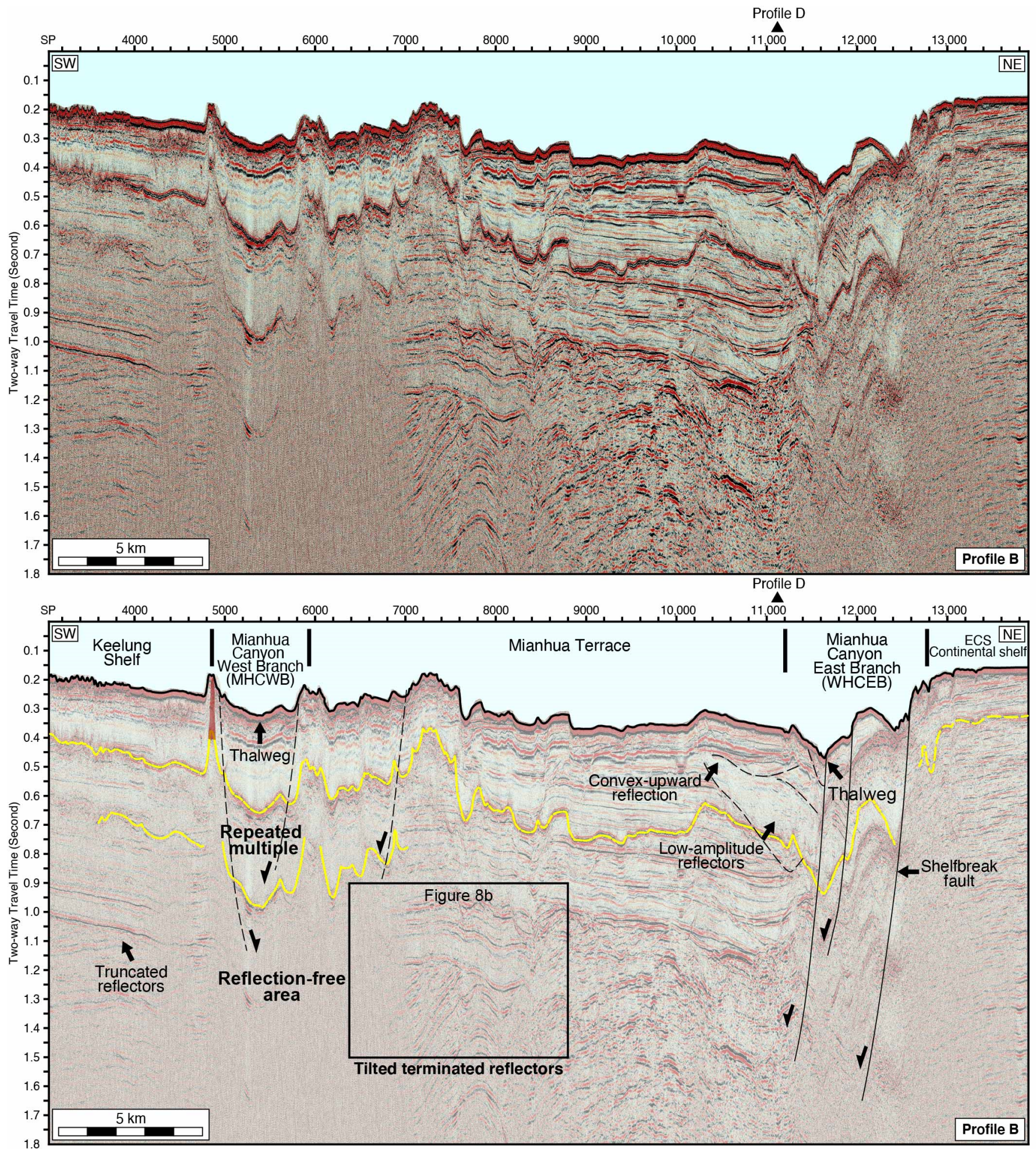

Figure 5. MCS data of Profile B across the Mianhua Terrace in the NE-SW direction. Brown area indicates the volcanic extrusion. Yellow lines indicate seafloor multiples. 


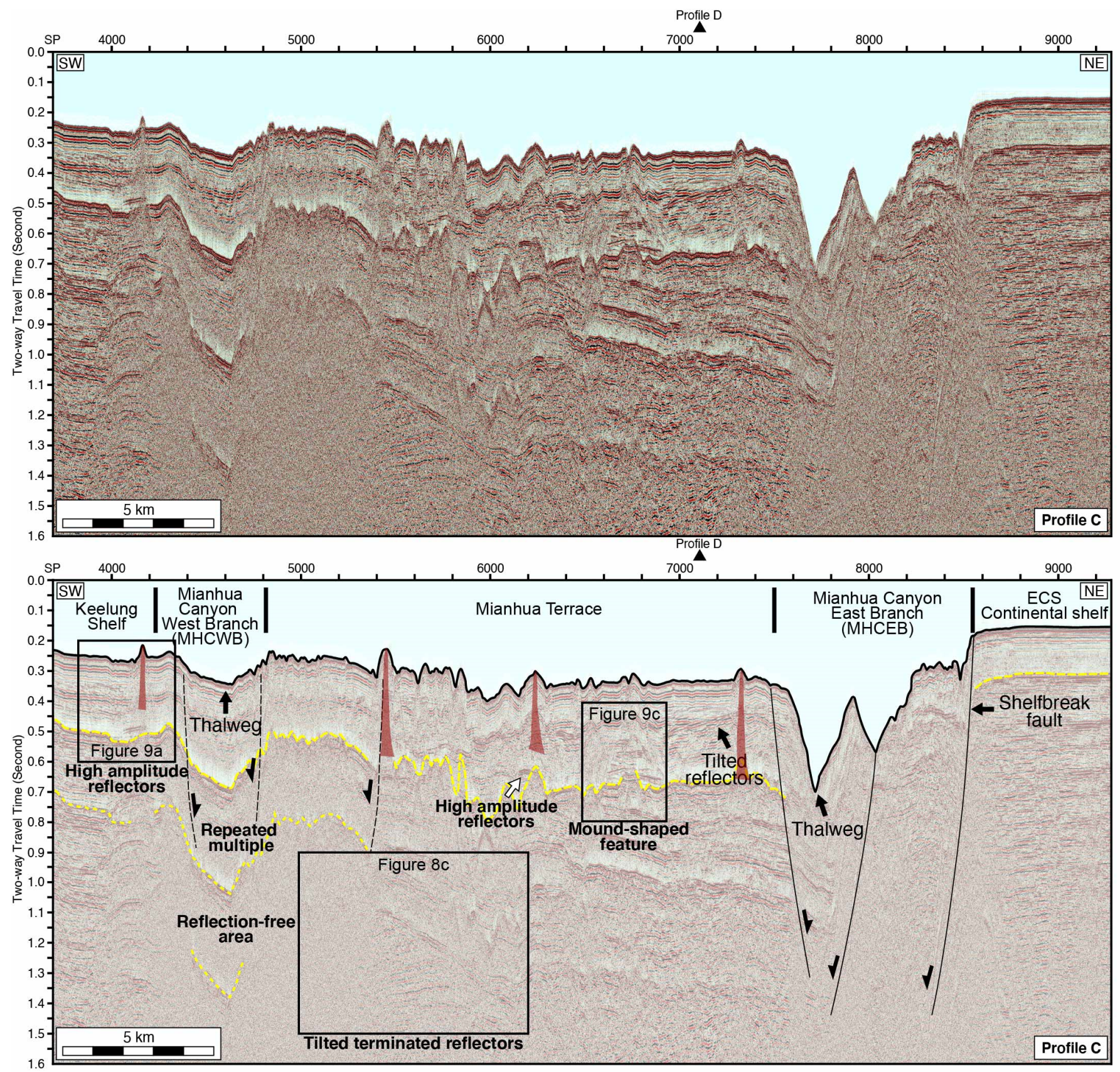

Figure 6. MCS data of Profile C across the Mianhua Terrace in the NE-SW direction. Brown areas indicate the volcanic extrusions. Yellow lines indicate seafloor multiples. 


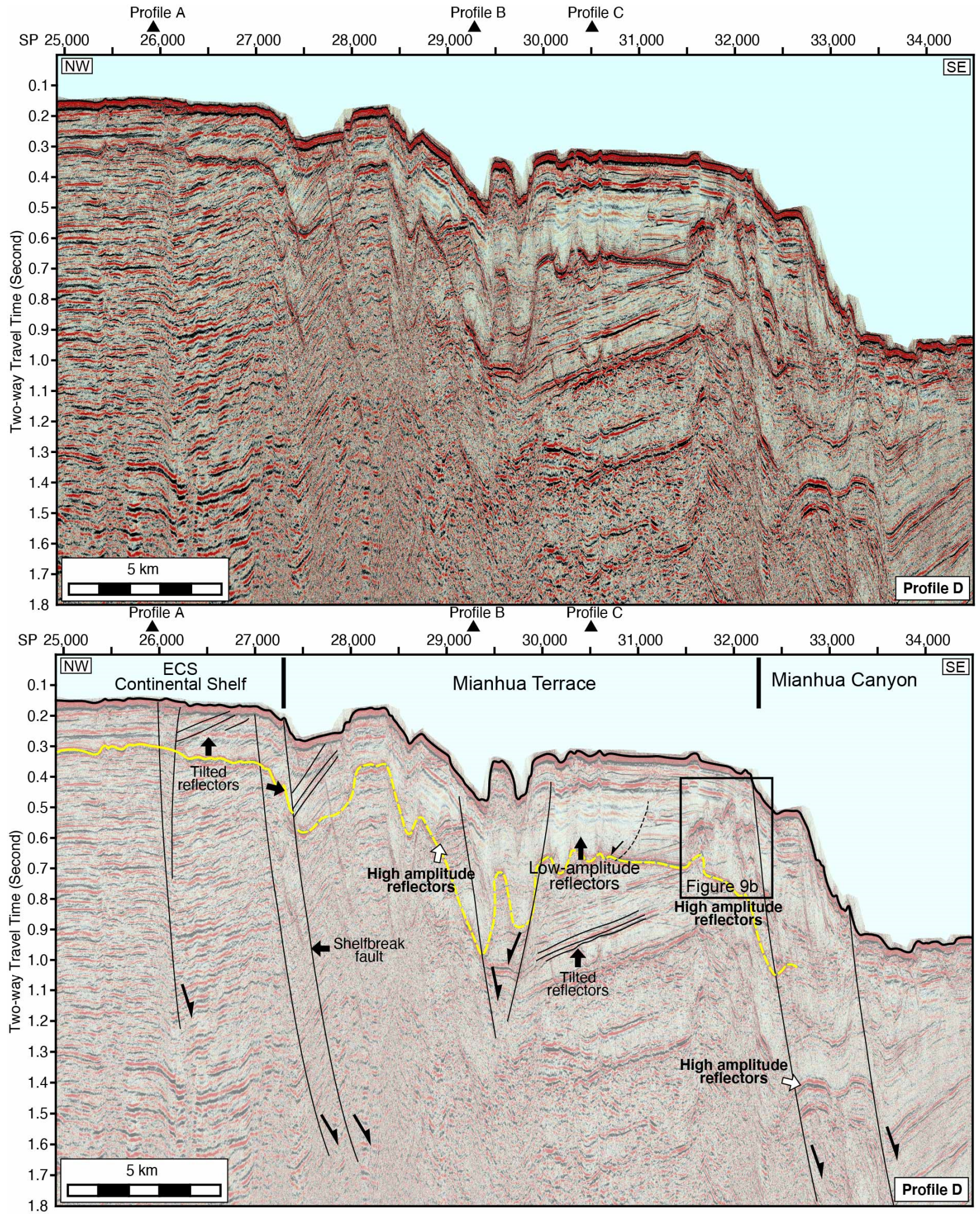

Figure 7. MCS data of Profile D across the Mianhua Terrace in the NW-SE direction. Yellow lines indicate seafloor multiples. 


\section{Results}

\subsection{Regional Stratigraphy and Structure}

A distinctive stratigraphic feature that we could observe in most of our MCS profiles is a group of terminated reflectors and an overlying truncating, unconformable surface (Figure 8). This stratigraphic feature can be generally observed beneath the western part of the Mianhua Terrace at about 1 second in depth. Here, we followed Hsiao et al. (1998) [12] and Chang et al. (2017) [13] and interpreted this unconformable surface as the stratigraphic boundary that separates the Late Miocene and Pleistocene, the so-called Pleistocene regional sequence boundary (PRSB) in the work of Hsiao et al. (1998) [12]. The stratigraphic sequences overlying and underlying the PRSB are post-collisional sedimentary sequences and pre-collisional Tertiary strata, respectively. Despite being a distinctive stratigraphic feature, the PRSB does not seem to be consistently visible and becomes covered by reflectionfree areas beneath repeated seafloor multiples.

Some sedimentary features can be observed close to the MHCEB in the eastern part of the Mianhua Terrace. For instance, low-amplitude reflectors underlying concave-upward features are found west of the thalweg of the MHCEB (dash lines in SP 10,200-11,600 in Figure 5). We interpreted these low amplitude reflectors and concave-upward features as sedimentary features in association with slope failures and canyon head erosion during the early stage of channel development. In contrast, the concave-upward features observed in Profile B are not visible in Profile C, probably indicating that no channel sediments were deposited along the trend of Profile C. We should also note that normal faults are the main structures in this area, indicating that structural activities played a dominant role in the development of the Mianhua Terrace. We suggest that the MHCEB was initially formed by normal fault structures and then dominated by subsequent downslope processes and probably mass transportation deposits (MTD).

Normal faults are the predominant structures in this area. Tilted reflectors bounded by normal faults can be observed not only within the Mianhua Terrace (SP 7000-7400 in Figure 6; SP 30,000-31,000 in Figure 7) but also to the west of the Mianhua Terrace (SP 26,000-27,000 in Figure 7), showing a series of rotating fault blocks. Clearly, they represent the collapsed orogenic wedge in the extensional strain regime.
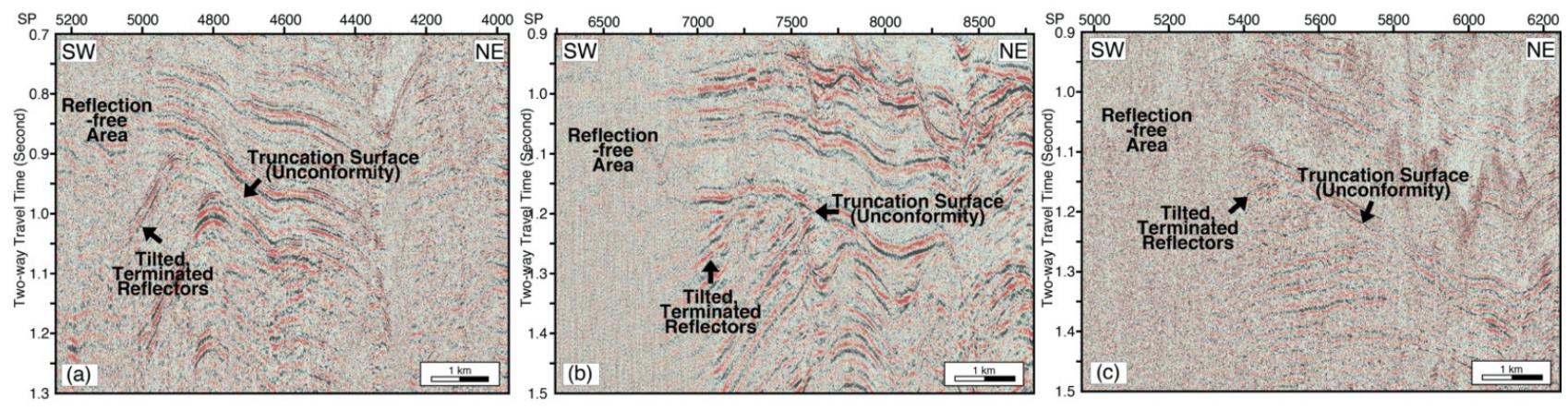

Figure 8. Terminated reflectors and truncating, unconformable surface. (a) Tilted reflectors revealed in Profile A (Figure 4). (b) Tilted reflectors revealed in Profile B (Figure 5). (c) Tilted reflectors revealed in Profile C (Figure 6).

\subsection{Seafloor Semi-Circular Structures}

The $200 \mathrm{~m}$ isobath divides Mianhua Terrace into a shallow part (shallower than $200 \mathrm{~m}$ ) in the west and a deeper part (200-500 m) in the east (Figure 3). A noticeable bathymetric feature of semicircular lineations close to the shelf break fault and the Mianhua Islet can be observed (empty arrows in Figure 3). Among them, two semicircular-shaped lineations are located between the Mianhua and Huaping Islets, and one is located east of Mianhua Islet. In addition, a near-circular sag marked by the $300 \mathrm{~m}$ isobath occurs within the semicircular lineation (filled arrow in Figure 3). These semicircular shapes are 1.5-2.5 km in diameter and cover areas of $5-10 \mathrm{~km}^{2}$. All of these semicircular lineations are located 
not only very close to the Quaternary volcanic Mianhua Islet but also close to the shelf break fault, which were able to facilitate the upward migration of subsurface magma. Thus, we speculate that semicircular lineations are volcanic edifices and are likely to have formed in association with the Quaternary volcanism process. These could have been craters or calderas in the very beginning that were deformed by subsequent eruption events and collapses, ultimately leading to a semicircular shape. To address the origin and formation of this morphological feature, more detailed survey work, including seafloor mapping, subsurface structure analysis, and sampling, needs to be conducted.

\subsection{Seafloor Hard Rock}

Beneath the Mianhua Terrace, the truncated reflectors and the overlying angular, unconformable surface can be observed. They can be found between SP 4400 and 5000 at around 0.9-1.0 s in Profile A (Figures 4 and 8a), between SP 7000 and 8400 at around 1.1-1.3 s in Profile B (Figures 5 and 8b), and between SP 5400 and 6000 at around 1.1-1.4 s in Profile C (Figures 6 and 8c). Generally, these features seem to become deeper toward the southeast. According to the drilling results and previous studies [12,13], this is an unconformity of great regional importance that separates the overlying Pleistocene strata from the underlying Late Miocene strata, and it was recognized as the cessation of collision and the beginning of the collapse of the Taiwan orogenic wedge.

This angular, unconformable surface is the most significant stratigraphic feature in our seismic sections and is widely recognized. While it becomes obscure and invisible westward where the tortuous and winding $200 \mathrm{~m}$ isobath occurs, we found that the subsurface reflection's seismic feature beneath the seafloor of the western part of the Mianhua Terrace is dominated by repeated seafloor multiples (SP 5400-6000 in Figure 4, SP 5000-7000 in Figure 5, and SP 4800-5400 in Figure 6). Toward the depths, repeated seafloor multiples seem attenuated and reflection-free patterns start to dominate, resulting in a barrier to recognizing the stratigraphic, unconformable surface. Fortunately, the angular, unconformable surface can be commonly observed west of the repeated seafloor multiples and underlying reflection-free signals (e.g., SP 3200-4600 and SP 7000-8400 in Figure 5), not only suggesting that strata at their correlatable level of depth obscured by the reflection-free signals should have shown unconformable relationships but also confirming that this angular unconformable surface is widespread. We consider that the repeated seafloor multiples and reflection-free signals that dominate the western part of the Mianhua Terrace most plausibly resulted from the physically hard lithology near the seafloor. Thus, in a similar manner to what was observed on the nearby Mianhua and Pengjia Islets, we suggest that the repeated seafloor multiples and reflection-free signals imply that the lithology of the seafloor and substratum is likely dominated by volcanic lavas.

We estimated the coverage of the possible volcanic seafloor on the basis of the projected seafloor area of the repeated seafloor multiples and reflection-free signals since they could be indicators of the influence of the seafloor and substratum volcanic materials. Here, an area of $240 \mathrm{~km}^{2}$ was estimated (Figure 3). We also note that this area seems to be distributed at the eastern bank of the MHCWB and approximately parallel to the main thalweg of the MHCWB (Figure 3), probably indicating that they shared a similar origin. Repeated seafloor multiples as an indicator of volcanic seafloor and substratum can also be applied to our study area of the East China Sea continental shelf, where we found a multiple that could repeat up to seven times (empty arrows in Figure 4).

\subsection{Intrusive Sills and Associated Extrusive Edifices}

The MHCWB is the main seafloor depression at the western part of the Mianhua Terrace. In Profiles B and C, the reflectors beneath this channel are too severely obscured by seafloor multiple to see their dips. In Profile A, however, it seems that the reflectors of both sides of the MHCWB dip toward the thalweg and that both sides of the MHCWB are dominated by an inward-dipping normal fault. Thus, we propose that it is a structurally dominated seafloor feature. We also note that it is characterized by a seafloor edifice west 
of the MHCWB (SP 6800 in Profile A, SP 4800 in Profile B, and SP 4200 in Profile C; Figure 4, Figure 5, and Figure 6, respectively). More specifically, a significant feature found in Profile $\mathrm{C}$ is that the parallel high-amplitude reflectors are recognized directly beneath the seafloor edifice (Figure 9a).

We consider that there may be a causal relationship between the high-amplitude reflectors and their projected seafloor edifice (Figures 6 and 9a). We thus interpreted the high-amplitude reflectors as intrusive sills and the projected pinnacle-shaped seafloor relief as the corresponding volcanic extrusive edifice. A similar observation was made by Magee et al. (2013) [43]. We additionally note that this seafloor edifice observed in Profiles A, B, and $\mathrm{C}$ appears to occur along the MHCWB, indicating that the upward movement of the extrusive magma may not solely occur via a tabular pathway (i.e., 1D) or be derived from a point source. It is more likely to occur via a planar conduit (i.e., 2D) or be derived from a linear source. Nearby fault structures are often suggested to serve as planar conduits for magma to emplace $[44,45]$. Thus, we propose that the fault systems, which may also be responsible for the development of the nearby $\mathrm{MHCWB}$, are a superior candidate for the conduit for magma migration.

According to the bathymetric chart and the MCS data, the dimension of this extrusive seafloor edifice was estimated to be generally $500 \mathrm{~m}$ in width and approximately elongates at most $40 \mathrm{~km}$ in length. Regarding the combination of the abovementioned observations of the NW-SE trending $200 \mathrm{~m}$ isobaths, repeated seafloor multiples and underlying reflectionfree signals, and the pinnacle-shaped seafloor relief with underlying high-amplitude reflectors, we suggest that the seafloor and substratum of the western part of the Mianhua Terrace may be dominated by physically hard, most likely volcanic-associated sediments, and that these volcanic features are probably structurally controlled, most likely by the post-collisional normal faults.

\subsection{Intrusive Sills Near Fault Structures}

High-amplitude reflectors are commonly recognized in our study area, especially in Profile D (Figures 7 and 9b). In profile D, they can be observed between SP 29,000 and 29,500 at around $0.6 \mathrm{~s}$. In addition, high-amplitude reflectors can be observed close to the boundary between the Mianhua Terrace and the MHCEB at both shallow (SP 31,500-32,300 at $0.5-0.6 \mathrm{~s}$ ) and deep levels (SP 32,500-33,000 at 1.4-1.5 s).

We note that these high-amplitude reflectors in Profile $\mathrm{D}$ are generally lie very close to normal fault structures. The high-amplitude reflectors located between SP 29,000 and 29,500 are close to the fault between the East China Sea Shelf and the Mianhua Terrace. The high-amplitude reflectors located between SP 31,500 and 33,000 are close to the fault between the Mianhua Terrace and the MHCEB. We suggest that high-amplitude reflectors indicate intrusive sills. The fault structures in the vicinity of the high-amplitude reflectors are clearly the conduits for the magma flow, facilitating the emplacement of the magmatic materials.

\subsection{Mound-Shape Features}

Igneous and volcanic features are shown in various forms in the Mianhua Terrace. In addition to the high-amplitude reflectors, we note that a mound-shaped feature with generally good continuity and moderate- to high-amplitude reflectors inside is observed in Profile C (SP 6600-7000; Figures 6 and 9c). Regarding volcanic processes, we interpreted the mound-shaped feature as a volcanic-associated mound that was probably discharged by magma intrusion or associated events at depth.

In our data, this mound-shaped feature seems to have gentle flanks $\left(\sim 6^{\circ}\right)$, a small summit height of $\sim 100 \mathrm{~m} \mathrm{(0.3} \mathrm{s)} \mathrm{and} \mathrm{a} \mathrm{diameter} \mathrm{of} \sim 2000 \mathrm{~m}$. This summit height and basal diameter ratio seems to better follow the morphological trends of a hydrothermal mound, as suggested by Magee et al. (2013) [43]. That is, compared with an extensive shield volcano, this mound's features appear more similar to a volcanogenic, dome-shaped hydrothermal vent. Accordingly, we suggest that the Mianhua Terrace may be not only a 
volcanic field but also a hydrothermal field. The hydrothermal vent could be found with a detailed marine geophysical survey.
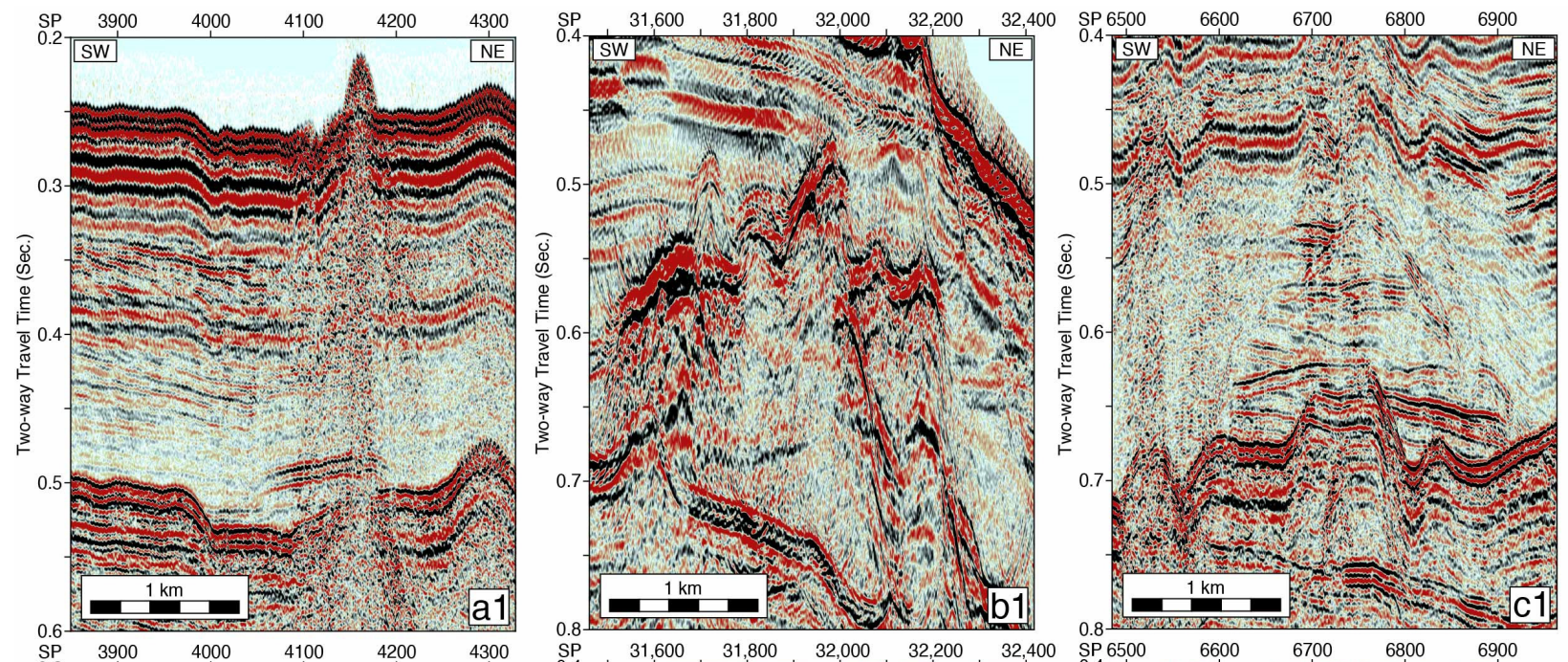

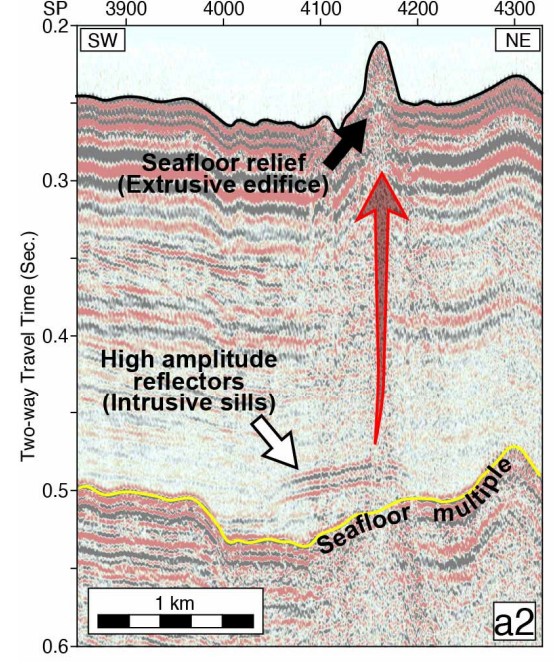

(a)

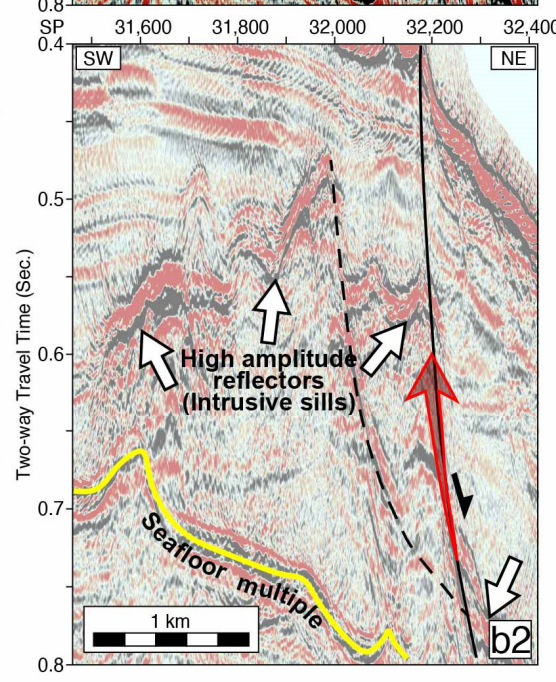

(b)

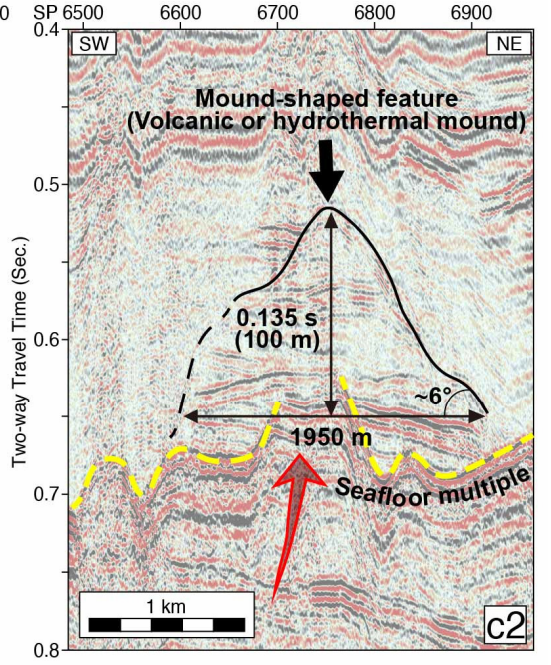

(c)

Figure 9. Close-up views of the volcanic-associated features in the Mianhua Terrace, including intrusive sills and corresponding extrusive edifice (a), intrusive sills with feeder fault structures (b), and the mound-shaped feature (c). See Sections 4.4-4.6 for more details. $(\mathbf{a 1}, \mathbf{b 1}, \mathbf{c 1})$ are uninterpreted data. $(\mathbf{a} 2, \mathbf{b} 2, \mathbf{c} 2)$ are interpreted data.

\subsection{Potential Field Data}

It is generally considered that potential field data can help reveal the existence of subsurface structures, especially igneous rocks that can produce geophysical anomalies. Thus, distribution maps of gravity (free air) and magnetic anomalies derived from the global dataset were prepared (Figure 10). These show that the main gravity and magnetic anomalies trend in more or less the NE-SW direction, corresponding to the trends of regional NE-SW geological structures. However, it appears that no potential field features can be observed in the known igneous area (orange area in Figure 10). Similarly, there are no distinctive potential field features that can be identified in our MCS survey area (orange and red areas in Figure 10). We ascribe these observations to the resolution of the available potential field data. The global potential field that we used is better suited to largescale geological features that can produce long-wavelength geophysical features. Thus, the volcanisms we observed in our MCS data are local events and may not be recognized in global potential field data. The collection and compilation of the current potential field 
data in offshore Northern Taiwan will be an important task that may help to better resolve local volcanisms.

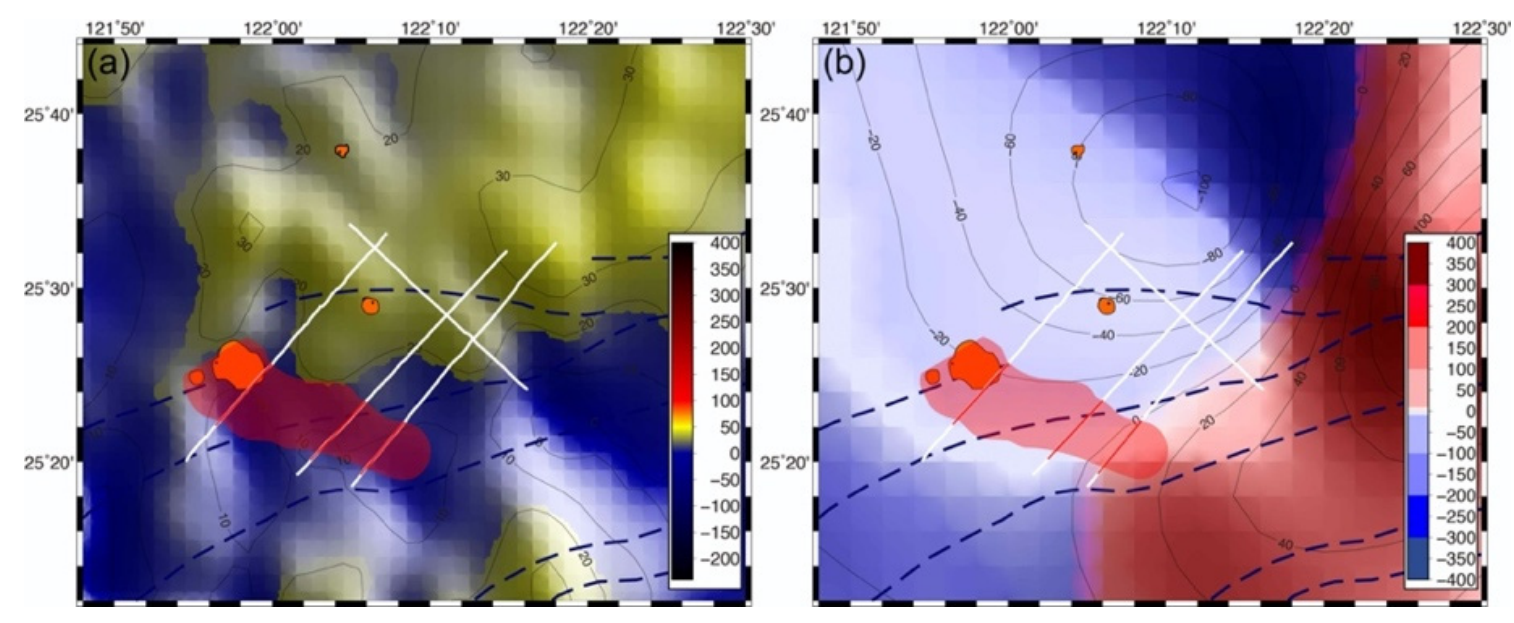

Figure 10. Distributions of potential fields. (a) Gravity anomaly and (b) magnetic anomaly. Orange and red areas indicate the distribution of the known igneous rocks and lavas observed in this study. Units are in mGal and nT, respectively.

\subsection{Summary}

Here, we summarize our results in terms of the distribution of volcanic features observed in the Mianhua Terrace. In the westernmost of the Mianhua Terrace, volcanic dikes are characterized by extrusive volcanic edifices (Figures 4-6) and subsurface intrusive sills (Figures 6 and 9a). Based on bathymetric data, it seems that the observed volcanic edifices extend in the NW-SE direction along the thalweg of the Mianhua Canyon West Branch (Figure 3). Eastward, near-surface lava flows resulting in a physically hard seafloor or substrate can be widely observed, as presented by repeated seafloor multiples and underlying reflection-free patterns that interrupt the continuity of subsurface reflectors east of the Mianhua Canyon West Branch (Figures 4-6). According to the distribution of this lava flow (red area in Figures 10 and 11), it appears to extend in the NW-SE direction, similar to the orientation of the extrusive volcanic edifice to the west.

East of the lava flow area, the seafloor is characterized by uneven and irregular bathymetry, suggesting that the seafloor is very likely dominated by more than seafloor sedimentation, probably volcanic or associated hydrothermal processes. A subsurface unconformity lies at around 1 second two-way travel time beneath the eastern part of the Mianhua Terrace, presenting as a regional stratigraphic boundary in its depths. Eastward, intrusive sills are observed along the normal faults (Figures 7 and $9 \mathrm{~b}$ ), suggesting that the formation of sills may be facilitated by extensional normal faults. A mound-shaped feature is also observed in the depths of the Mianhua Terrace (Figures 6 and 9c).

\section{Discussion}

\subsection{Formation and Implication of the Mianhua Terrace}

Offshore Northern Taiwan is currently experiencing the collapse of a mountain below sea level, which is dominated by normal faults. These normal faults run mainly in the NESW direction along the strike of the Taiwan orogenic wedge. It appears that the formation of the Mianhua Terrace is closely associated with the normal fault activity. Here, a model of a breached ramp in a transfer zone associated with the development of an extensional normal fault system is proposed to explain the formation of the Mianhua Terrace.

In the beginning, a fault population in a similar NE-SW direction occurred in response to regional extensional strain (Figure 11a). These faults may have developed independently with their tips underlapped along the shelf break. As the extension persisted and normal faults continued to grow, the underlapped fault tips approached, reached, and passed the immediate tips, turning into overlapping ones (Figure 11b). Toward the overlapping 
fault tips, a strike ramp [46] or relay ramp [47] was generated and reflected in shallow bathymetry (Figure 11c). Eventually, the ramp may have broken to form a breached relay ramp as a wide damage zone. Accompanied with the deformation along the shelf break and the formation of the relay ramp, local volcanism may have also been facilitated by the extension of the normal faults and take place contemporarily, resulting in intrusive sills and various extrusive seafloor edifices like those we can observe on and near the Mianhua Terrace.

We should note that the breaching of the continental shelf break is likely to be a mechanism for seafloor failure events and may be catastrophic. That is, submarine landslides and tsunamis may be induced and have devastating influence on neighboring areas (i.e., the coastal area of Northern Taiwan) [48]. A detailed inspection of the fault structures within and near the Mianhua Terrance will help constrain how the geohazard events may occur and will be a required task in terms of geohazard mitigation.

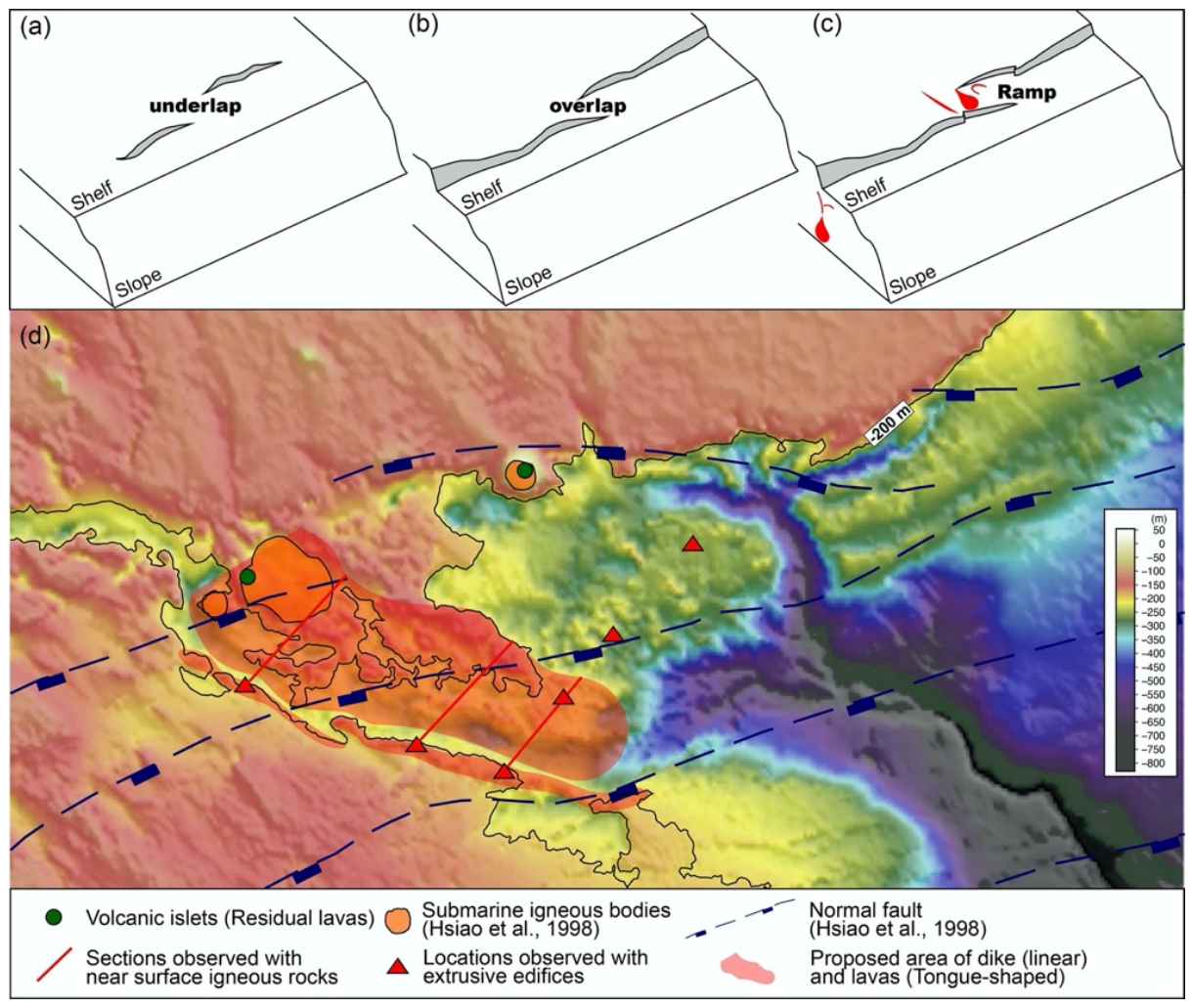

Figure 11. Development of a relay ramp via the approaching (a), passing (b), and overlapping (c) of the fault tips. The red rectangle in (d) indicates the area of possible and associated volcanic features.

\subsection{Origin, Ages and Implication of the Magmatic Features}

In the NTVZ, two different magma sources have been identified-a depleted asthenosphere mantle and a metasomatized lithospheric mantle [15]. In addition, from the NE to the SW in the NTVZ, the magma shows systematic compositional variations from low-K to calc-alkaline and shoshonitic series [15]. Since differences in magma sources can lead to compositional variations, it seems possible that the origin of the NTVZ magmatism can also be revealed in terms of styles of magma intrusion and extrusion. In the onshore area of the NTVZ, lavas, pyroclastic flow deposits, and intrusive stock are all observed. In the offshore area, in addition to lavas and pyroclastic flow deposits observed on Pengjia and Mianhua Islets, we found not only seafloor extrusive edifices but also subsurface intrusive sills, indicating that the volcanisms in the NTVZ may be similar in terms of eruptions. The consistency between onshore and offshore volcanism suggests that our current observations in the NTVZ may not directly reveal deep Earth mantle processes. 
As we know that offshore Northern Taiwan is in a stage of extensional collapse of the Taiwan orogenic wedge and that the Mianhua Terrace is plausibly a collapsed breached ramp between two immediate and approaching fault tips, we can suggest that the extensional normal fault structures predominate within this area. In this regard, extensional normal fault structures may not only serve as a main structural feature but also play additional roles within the extensional structural framework. As noted, most of the highamplitude reflectors observed in the Mianhua Terrace are sitting in the vicinity of normal fault structures. It is also possible that igneous rocks were formed prior to magmatism and are pre-existing features. Both fault activities and magmatism are currently active in the NTVZ and are represented by the seafloor faults and near-seafloor volcanic lavas in our MCS data. In addition, there were no known large-scale igneous events prior to the collapse of the Taiwan orogenic wedge and magmatism of the NTVZ. It seems more reasonable that high-amplitude reflectors and normal fault structures are very likely associated in a causal relationship.

More interestingly, the high-amplitude reflectors in our MCS data occur not only at different sides of the boundary fault between the Mianhua Terrace and the MHCEB but also at different levels of depth. Presumably, the high-amplitude reflectors in various levels of depth suggest different events of magma emplacement. We may further suggest that the formation of the volcanic sills close to the normal faults depended greatly on magma emplacement within these fault structures. Hence, normal faults in this setting represent not only the result of the extensional collapse but also the contributor and facilitator of post-collisional magmatism events.

Magma emplacement and the hydrothermal fluid system facilitated by transfer faulting in extensional settings appear common. In the Taupo Volcanic Zone, New Zealand, 60\% of the geothermal fields are located in accommodation zones between rift segments, suggesting that permeability is locally enhanced by fault structures associated with transferring stress [49]. In central Italy, the regional NW-SE faults occur together with associated NESW transfer faults [50]. Interestingly, the volcanisms mainly occur at the intersection among the NW-SE and NE-SW faults, showing that the generation and ascension of magma are controlled by the regional NW-SE fault and that the magma ascent and emplacement at the shallow level are controlled by NE-SW transferring structures. It was recently reported that a transfer zone can be a pull-apart basin with coeval activities of different strikes and with favorable weak zones where fluid and magma can be channeled from depths toward the shallow level [51]. Clearly, structures in a transfer zone will facilitate the formation of local volcanic and hydrothermal events in offshore Northern Taiwan.

The igneous and volcanic features observed in the Mianhua Terrace can be ascribed to post-collisional magmatism events of the NTVZ and correlated to at least one of the three age groups (before 2.6 Ma, 2-1 Ma, and after $1 \mathrm{Ma}$ ) of the NTVZ [15]. We first note that the late age group (after $1 \mathrm{Ma}$ ) occurred in all areas, suggesting that the third event could account for the observed volcanic features in the Mianhua Terrace. Second, we observed that the Pengjia Islet (PJI) includes the middle (2-1 Ma) and late age group and that the Mianhua Islet (MHI) includes the early (before $2.6 \mathrm{Ma}$ ) and late age group. It appears that the event of the late age group is the superior candidate to account for the volcanic events of the Mianhua Terrace.

Though neither the MHI nor PJI volcanic groups exhibit extreme shoshonitic characteristics that are most diagnostic of post-collisional magmatism, the rest of the late age group (Kobisho (KBS), Kuanyinshan (KYS), and Tsaolingshan (TLS)) have high-K calcalkaline to shoshonitic-ultrapotassic characteristics, in addition to extreme enrichment in LREE (light rare earth elements, i.e., La, Nd, Sm, and Gd) and LILE (large ion lithophile elements, i.e., $\mathrm{K}, \mathrm{Rb}, \mathrm{Sr}, \mathrm{Cs}, \mathrm{Ba}$, and LREE), but HFSE (high field strength elements; i.e., $\mathrm{Nb}$, $\mathrm{Ta}$, and Ti) depletion. Thus, it is more reasonable that they resulted from a combination of tectonic and magmatic processes led by a unique interaction of collision-extensionsubduction [15]. That is, a reverse geochemical pattern that starts with asthenospheric melt and then proceeds to lithospheric melt is possible, as can be seen in the Betic-Alboran 
region of southeastern Spain [15]. Moreover, the Mianhua Terrace, situated in a transfer zone, is a secondary structure under regional extension of post-collision, as proposed in Section 5.1. The late age groups in the MHI and PJI possibly formed as a result of the volcanism associated with the latest secondary structural activities. Therefore, we currently suggest that the transfer zone igneous and volcanic features observed in the Mianhua Terrace are related to the late age group of the NTVZ.

It is also important to further confirm if the volcanic feature we observed along fault structures could be active. If so, a complete assessment of possible volcanism-associated geohazards will be a crucial task to conduct. Therefore, the future development of the Mianhua Terrace and local volcanisms should be included as possible geohazards in offshore Northern Taiwan. In addition, the mound-shaped feature we observed in the eastern part of the Mianhua Terrace suggests that not only volcanic but also hydrothermal events may have occurred. In Northern Taiwan, hydrothermal systems are significant because they are responsible for hydrothermal alteration and associated mineralization for gold-copper deposits $[17,18]$. Recent marine geophysical investigations have suggested that numerous volcanic gas flares or hydrothermal plumes have occurred in offshore Northern Taiwan, indicating that emissions of volcanic gas are presently active and that the hydrothermal system can be extended offshore [23]. Situated along this extension, the Mianhua Terrace is expected to not only be a volcanic field but also host present and former hydrothermal activity similar to mining sites of great economic value in Northern Taiwan. Marine investigation in this area will be helpful to explore new possibilities.

\section{Conclusions}

Using recently compiled bathymetric data and MCS data, we present the stratigraphic, structural, and volcanic features in the Mianhua Terrance, offshore Northern Taiwan. Seafloor features revealed by bathymetric and MCS data indicate that the seafloor is uneven and rugged with semi-circular and near-circular shaped lineations in the Mianhua Terrace. The MCS profiles indicate a Pleistocene unconformity is buried beneath the Mianhua Terrace and separates post-collision sediments from a collapsed fold-thrust belt. The unconformity is partly difficult to be observed due to obstacles from seafloor multiples, indicating that the material covering the seafloor is physically hard and mostly likely to be volcanic lavas. In our MCS profiles, normal faults and volcanic sills are also commonly observed in the Mianhua Terrace. Remarkably, volcanic sills are observed beneath a seafloor pinnacle-shaped feature and very close to fault structures, suggesting that the emplacement of the volcanic intrusive sills and the formation of the volcanic edifices are very likely facilitated by fault structures to a large extent.

Based on our observation on bathymetry and MCS profiles, it appears that the Mianhua Terrace is a distinct area and predominated by fault structures that not only resulted in the formation of the Mianhua Terrace and Mianhua Canyon but also serve as conduits for volcanism to develop along. We propose that the Mianhua Terrace is sitting in a ramp of a transfer zone between the tips of two successive normal faults along the shelf break. Once the faults reactivate, the tips may extend toward each other, the Mianhua Terrace may continue to collapse, and associated volcanism may occur. We suggest that the Mianhua Terrace is not only an active volcanic field but also likely a prospective site with hydrothermal events and associated mineralization.

Author Contributions: Conceptualization, J.-H.C. and T.-T.C.; methodology, J.-H.C., E.Y.-C.Y., and H.-H.H.; software, J.-H.C., E.Y.-C.Y., and H.-H.H.; investigation, J.-H.C., E.Y.-C.Y., H.-H.H., C.-S.L., and S.-D.C.; resources, C.-S.L.; data curation, J.-H.C., E.Y.-C.Y., and H.-H.H.; writing-original draft preparation, J.-H.C. and H.-H.H.; writing-review and editing, J.-H.C. and H.-H.H.; supervision, C.-S.L.; project administration, C.-S.L.; funding acquisition, C.-S.L. All authors have read and agreed to the published version of the manuscript.

Funding: This research was partly funded by Bureau of Mines, Ministry of Economic Affairs, Taiwan. 
Acknowledgments: We appreciate technicians in Marine Exploration Instrument Center, captain and crew members on R/V Ocean Research 2, for help with MCS data collection.

Conflicts of Interest: The authors declare no conflict of interest.

\section{References}

1. Turner, S.; Arnaud, N.; Liu, J.; Rogers, N.; Hawkesworth, C.; Harris, N.; Kelley, S.; van Calsteren, P.; Deng, W. Post-Collision, Shoshonitic Volcanism on the Tibetan Plateau: Implications for Gonvective Thinning of the Lithosphere and the Source of Ocean Island Basalts. J. Petrol. 1996, 37, 45-71. [CrossRef]

2. Chung, S.-L.; Chu, M.-F.; Zhang, Y.; Xie, Y.; Lo, C.-H.; Lee, T.-Y.; Lan, C.-Y.; Li, X.; Zhang, Q.; Wang, Y. Tibetan Tectonic Evolution Inferred from Spatial and Temporal Variations in Post-Collisional Magmatism. Earth Sci. Rev. 2005, 68, 173-196. [CrossRef]

3. Seghedi, I.; Maţenco, L.; Downes, H.; Mason, P.R.D.; Szakács, A.; Pécskay, Z. Tectonic Significance of Changes in Post-Subduction Pliocene-Quaternary Magmatism in the South East Part of the Carpathian-Pannonian Region. Tectonophysics 2011, 502, 146-157. [CrossRef]

4. $\quad$ Lin, Y.-C.; Chung, S.-L.; Bingöl, A.F.; Yang, L.; Okrostsvaridze, A.; Pang, K.-N.; Lee, H.-Y.; Lin, T.-H. Diachronous Initiation of Post-Collisional Magmatism in the Arabia-Eurasia Collision Zone. Lithos 2020, 356-357, 105394. [CrossRef]

5. Dewey, J.F. Extensional Collapse of Orogens. Tectonics 1988, 7, 1123-1139. [CrossRef]

6. Fossen, H.; Rykkelid, E. Postcollisional Extension of the Caledonide Orogen in Scandinavia: Structural Expressions and Tectonic Significance. Geology 1992, 20, 737-740. [CrossRef]

7. Fossen, H. Extensional Tectonics in the Caledonides: Synorogenic or Postorogenic? Tectonics 2000, 19, 213-224. [CrossRef]

8. Gögüş, O.H.; Pysklywec, R.N.; Faccenna, C. Postcollisional Lithospheric Evolution of the Southeast Carpathians: Comparison of Geodynamical Models and Observations: Geodynamic models for the se carpathians. Tectonics 2016, 35, 1205-1224. [CrossRef]

9. Teng, L.S. Geotectonic Evolution of Late Cenozoic Arc-Continent Collision in Taiwan. Tectonophysics 1990, 183, 57-76. [CrossRef]

10. Liu, T.-K.; Hsieh, S.; Chen, Y.-G.; Chen, W.-S. Thermo-Kinematic Evolution of the Taiwan Oblique-Collision Mountain Belt as Revealed by Zircon фssion Track Dating. Earth Planet. Sci. Lett. 2001, 186, 45-56. [CrossRef]

11. Teng, L.S. Extensional Collapse of the Northern Taiwan Mountain Belt. Geology 1996, 24, 949-952. [CrossRef]

12. Hsiao, L.-Y.; Lin, K.-A.; Huang, S.-T.; Teng, L.S. Structural Characteristics of the Southern Taiwan-Sinzi Folded Zone. Pet. Geol. Taiwan 1998, 32, 133-153.

13. Chang, J.-H.; Yang, E.Y.-C.; Hsu, H.-H.; Su, C.-C.; Liu, C.-S.; Chiu, S.-D.; Ma, Y.-F.; Li, Y.-W.; Lin, Y.-C.; Shen, J.-S. Seismic Stratigraphic Features of the Late Miocene-Present Unconformities and Related Seismic Units, Northern Offshore Taiwan. In Seismic and Sequence Stratigraphy and Integrated Stratigraphy_New Insights and Contributions; Aiello, G., Ed.; InTech: Rijeka, Croatia, 2017; ISBN 978-953-51-3675-0.

14. Wang, K.-L.; Chung, S.-L.; Chen, C.-H.; Shinjo, R.; Yang, T.F.; Chen, C.-H. Post-Collisional Magmatism around Northern Taiwan and Its Relation with Opening of the Okinawa Trough. Tectonophysics 1999, 308, 363-376. [CrossRef]

15. Wang, K.-L. Geochemical Constraints for the Genesis of Post-Collisional Magmatism and the Geodynamic Evolution of the Northern Taiwan Region. J. Petrol. 2004, 45, 975-1011. [CrossRef]

16. Lin, C.-H. Evidence for a Magma Reservoir beneath the Taipei Metropolis of Taiwan from Both S-Wave Shadows and P-Wave Delays. Sci. Rep. 2016, 6, 39500. [CrossRef] [PubMed]

17. Wang, Y.; Sasaki, M.; Sasada, M.; Chen, C.-H. Fluid Inclusion Studies of the Chinkuashih High-Sulfidation Gold-Copper Deposits in Taiwan. Chem. Geol. 1999, 154, 155-167. [CrossRef]

18. Wang, Y. Physical and Chemical Characteristics of the Host Rocks in Controlling the Mineralization of the Chinkuashih HighSulfidation Gold-Copper Deposits, Northeastern Taiwan. J. Geochem. Explor. 2010, 104, 61-68. [CrossRef]

19. Chen, C.-H.; Shen, J.J.-S. A Refined Historical Record of Volcanic Eruptions around Taiwan: Tectonic Implications in the Arc-Continent Collision Area. Terr. Atmos. Ocean. Sci. 2005, 16, 331-343. [CrossRef]

20. Yu, H.-S. Nature and Distribution of the Deformation Front in the Luzon Arc-Chinese Continental Margin Collision Zone at Taiwan. Mar. Geophys. Res. 2004, 25, 109-122. [CrossRef]

21. Suppe, J. Kinematics of arc-continent collision, flipping of subduction, and back-arc spreading near Taiwan. In Memoir of the Geological Society of China; Geological Society of China (Taiwan): Taipei, Taiwan, 1984.

22. Teng, L.S.; Lee, C.T.; Peng, C.-H.; Chen, W.-F.; Chu, C.-J. Origin and Geological Evolution of the Taipei Basin, Northern Taiwan. West. Pac. Earth Sci. 2001, 1, 28.

23. Chen, C.-T.; Lee, J.-C.; Chan, Y.-C.; Lu, C.-Y.; Teng, L.S.-Y. Elucidating the Geometry of the Active Shanchiao Fault in the Taipei Metropolis, Northern Taiwan, and the Reactivation Relationship with Preexisting Orogen Structures: Resolving Shanchiao Fault Geometry. Tectonics 2014, 33, 2400-2418. [CrossRef]

24. Hung, T.-I. Geomorphologic Study Offshore the Jingshan Area; National Taiwan University: Taipei, Taiwan, 2013.

25. Tsai, C.-H.; Hsu, S.-K.; Lin, S.-S.; Yang, T.F.; Wang, S.-Y.; Doo, W.-B.; Lee, H.-F.; Lan, T.; Huang, J.-C.; Liang, C.-W. The Keelung Submarine Volcano in the Near-Shore Area of Northern Taiwan and Its Tectonic Implication. J. Asian Earth Sci. 2017, 149, 86-92. [CrossRef]

26. Juang, W.-S. Diversity and Origin of Quaternary Basalti Magma Series in Northern Taiwan. Collect. Res. 1993, 1, 125-166.

27. Chen, C.-H. Igneous Rocks of Taiwan; Central Geological Survey (Taiwan): Taipei, Taiwan, 1990. 
28. Wan, Y.; Ho, K.; Liu, D.; Zhou, H.; Dong, C.; Ma, M. Micro-Scale Heterogeneity of Andesite from Chilungshan, Northern Taiwan: Evidence from Melt Inclusions, Geochronology and Hf-O Isotopes of Zircons. Chem. Geol. 2012, 328, 244-258. [CrossRef]

29. Lai, Y.-M.; Liu, T.-C.; Chen, Y.-M.; Iizuka, Y. Melting and Crystallization of Andesite from Chilungshan, Northern Taiwan: An Experimental Petrological Study at Atmospheric Pressure. Quat. Int. 2014, 349, 221-231. [CrossRef]

30. Chen, W.-S.; Yang, C.-C.; Yang, H.-C.; Liu, J.-K. Volcanic landform and sequence of the Tatun Volcanoes. Bull. Cent. Geol. Surv. 2003, 99-123.

31. Belousov, A.; Belousova, M.; Chen, C.-H.; Zellmer, G.F. Deposits, Character and Timing of Recent Eruptions and Gravitational Collapses in Tatun Volcanic Group, Northern Taiwan: Hazard-Related Issues. J. Volcanol. Geotherm. Res. 2010, 191, $205-221$. [CrossRef]

32. Chung, S.-L.; Wang, K.-L.; Crawford, A.J.; Kamenetsky, V.S.; Chen, C.-H.; Lan, C.-Y.; Chen, C.-H. High-Mg Potassic Rocks from Taiwan: Implications for the Genesis of Orogenic Potassic Lavas. Lithos 2001, 59, 153-170. [CrossRef]

33. Yu, H.-S.; Hong, E. Physiographic Characteristics of the Continental Margin, Northeast Taiwan. Terr. Atmos. Ocean. Sci. 1992, 3, 419. [CrossRef]

34. Yu, H.-S.; Hong, E. The Huapinghsu Channel/Canyon System off Northeastern Taiwan: Morphology, Sediment Character and Origin. Terr. Atmos. Ocean. Sci. 1993, 4, 307. [CrossRef]

35. Yu, H.-S.; Shyu, C.-T. Topography, Geomagnetism and Structure in the Shelf-Slope Region off Northeastern Taiwan. J. Geol. Soc. China 1994, 37, 247-260.

36. Yu, H.-S.; Song, G.-S. Sedimentary Features of Shelf North of Taiwan Revealed by $3.5 \mathrm{KHz}$ Echo Character. Geology 1996, 35, 105-114.

37. Song, G.-S.; Chang, Y.-C.; Ma, C.-P. Characteristics of Submarine Topography off Northern Taiwan. Terr. Atmos. Ocean. Sci. 1997, 8, 461. [CrossRef]

38. Yu, H.; Lee, M.-L. Morphological and Seismic Characteristics of the North Mien-Hua Submarine Cany on off Northeastern Taiwan. Terr. Atmos. Ocean. Sci. 1998, 9, 263-278. [CrossRef]

39. Song, G.-S.; Ma, C.-P.; Yu, H.-S. Fault-Controlled Genesis of the Chilung Sea Valley (Northern Taiwan) Revealed by Topographic Lineaments. Mar. Geol. 2000, 169, 305-325. [CrossRef]

40. Yu, H.-S.; Song, G.-S. Physiographic and Geologic Frameworks of the Shelf-Slope Region off Northeastern Taiwan. Acta Oceanogr. Taiwanica 2000, 38, 1-22.

41. Sandwell, D.T.; Smith, W.H.F. Global Marine Gravity from Retracked Geosat and ERS-1 Altimetry: Ridge Segmentation versus Spreading Rate: GLOBAL MARINE GRAVITY. J. Geophys. Res. 2009, 114. [CrossRef]

42. Sandwell, D.T.; Müller, R.D.; Smith, W.H.F.; Garcia, E.; Francis, R. New Global Marine Gravity Model from CryoSat-2 and Jason-1 Reveals Buried Tectonic Structure. Science 2014, 346, 65-67. [CrossRef]

43. Magee, C.; Hunt-Stewart, E.; Jackson, C.A.-L. Volcano Growth Mechanisms and the Role of Sub-Volcanic Intrusions_Insights from 2D Seismic Reflection Data. Earth Planet. Sci. Lett. 2013, 373, 41-53. [CrossRef]

44. Valentine, G.; Krogh, K. Emplacement of Shallow Dikes and Sills beneath a Small Basaltic Volcanic Center-The Role of Pre-Existing Structure (Paiute Ridge, Southern Nevada, USA). Earth Planet. Sci. Lett. 2006, 246, 217-230. [CrossRef]

45. Magee, C.; Jackson, C.A.-L.; Schofield, N. The Influence of Normal Fault Geometry on Igneous Sill Emplacement and Morphology. Geology 2013, 41, 407-410. [CrossRef]

46. Fossen, H. Structural Geology; Cambridge University Press: Cambridge, UK, 2010; ISBN 978-0-511-77780-6.

47. Morley, C.K.; Nelson, R.A.; Munn, S.G. Transfer Zones in the East African Rift System and Their Relevance to Hydrocarbon Exploration in Riftsl. AAPG Bull. 1990, 74, 1234-1253.

48. Yu, N.-T.; Yen, J.-Y.; Chen, W.-S.; Yen, I.-C.; Liu, J.-H. Geological Records of Western Pacific Tsunamis in Northern Taiwan: AD 1867 and Earlier Event Deposits. Mar. Geol. 2016, 372, 1-16. [CrossRef]

49. Rowland, J.V.; Sibson, R.H. Structural Controls on Hydrothermal Flow in a Segmented Rift System, Taupo Volcanic Zone, New Zealand. Geofluids 2004, 4, 259-283. [CrossRef]

50. Acocella, V.; Funiciello, R. Transverse Systems along the Extensional Tyrrhenian Margin of Central Italy and Their Influence on Volcanism: Extension and volcanism in central Italy. Tectonics 2006, 25. [CrossRef]

51. Liotta, D.; Brogi, A. Pliocene-Quaternary Fault Kinematics in the Larderello Geothermal Area (Italy): Insights for the Interpretation of the Present Stress Field. Geothermics 2020, 83, 101714. [CrossRef] 